\title{
Factors associated with the prevalence of Otodectes cynotis in an ambulatory population of dogs ${ }^{1}$
}

\author{
Clarissa P. Souza ${ }^{2}$, Regina R. Ramadinha ${ }^{3}$, Fabio B. Scott ${ }^{2}$ and \\ Maria Júlia S. Pereira ${ }^{2}$
}

\begin{abstract}
Souza C.P., Ramadinha R.R., Scott F.B. \& Pereira M.J.S. 2007. Factors associated with the prevalence of Otodectes cynotis in an ambulatory population of dogs. Pesquisa Veterinária Brasileira 28(8):375-378. Departamento de Parasitologia Animal, Instituto de Veterinária, Universidade Federal Rural do Rio de Janeiro, Seropédica, RJ 23890-000, Brazil. E-mail: clarissa@ ufrrj.br

The objective was to evaluate the factors associated with the prevalence of Otodectes cynotis infestations in dogs assisted at the Dermatology Service of the Veterinary Hospital, Universidade Federal Rural do Rio de Janeiro. A total of 250 dogs were examined through direct smear of ear samples using a stereoscopic microscope, for the parasitological diagnostic. All dog owners were interviewed and data regarding the animals and their environments were individually recorded. Mite infestation was observed in 15 animals, with a prevalence of $6 \%$. The variables were tested regarding their association with the mites, using the $\chi^{2}$ test and, when appropriate, the Fisher exact test. There were no evidences that age $(p=0,20)$, sex $(p=0,31)$, breed $(p=0,50)$, shape of ear $(p=0,66)$, type $(p=0,19)$ and length of hair $(p$ $=0,14)$ and contact with other animals $(p=0,06)$ could act as potential risk factors for $O$. cynotis infestation. However, living environment $(p=0,03)$ and frequency of environmental cleaning $(p=0,005)$ may facilitate the infestation. The occurrence of pruritus was associated to the presence of mites $(p<0,001)$, suggesting to be an effect of the parasitism.
\end{abstract}

INDEX TERMS: Ear mange, risk factors, dogs.

RESUMO.- [Fatores associados à prevalência da infestação por Otodectes cynotis em uma população ambulatorial.] $\mathrm{O}$ objetivo deste estudo foi avaliar os fatores associados à prevalência da infestação por Otodectes cynotis em cães atendidos no Setor de Dermatologia do Hospital Veterinário de Pequenos Animais, Universidade Federal Rural do Rio de Janeiro. Foram atendidos 250 cães, sendo o diagnóstico feito através de visualização do ácaro, presente no cerumem coletado e examinado sob microscopia esterioscópica. Todos os proprietários dos cães foram entrevistados para preenchimento de fichas individuais com dados dos animais e do ambiente

\footnotetext{
${ }^{1}$ Received on October 8, 2007.

Accepted for publication on June 6, 2008.

2 Departamento de Parasitologia Animal, Universidade Federal Rural do Rio de Janeiro, Seropédica, RJ 23890-000, Brazil. "Corresponding author: clarissa@ufrrj.br

${ }^{3}$ Departamento de Medicina e Cirurgia Veterinária, Universidade Federal Rural do Rio de Janeiro, Seropédica RJ 23890-000, Brazil.
}

em que estes viviam. A infestação por 0 . cynotis foi observada em 15 animais, sendo a prevalência de $6 \%$. A associação entre as variáveis e a presença dos ácaros foi testada através do $\chi^{2}$ e quando pertinente pelo teste de Fisher exato. Não houve evidências que permitissem concluir que a idade $(p=0,20)$, o sexo $(p=0,31)$, a raça ( $p$ $=0,50)$, o formato das orelhas $(p=0,66)$, o tipo $(p=0,19)$ e comprimento da pelagem $(p=0,14)$ e, o convívio com outros animais $(p=0,06)$ poderiam atuar como possíveis fatores de risco para a infestação. Entretanto, o ambiente em que viviam os animais $(p=0,03)$ e a freqüência de limpeza $(p=0,005)$ parecem propiciar a infestação. A ocorrência de prurido esteve associada à presença dos ácaros $(p<0,001)$, sugerindo ser um efeito do parasitismo.

TERMOS DE INDEXAÇÃO: Sarna otodécica; fatores de risco; cães.

\section{INTRODUCTION}

Otodectes cynotis mites are big, white and very active parasites. They are highly contagious and can infest 
several species of animals (Scott et al. 2001). The mechanical irritation caused by the presence of the mites inside the ears may lead to a higher activity of ceruminal glands and, consequently, the establishment of a favorable environment for secondary infections by bacteria or fungi (August 1988). The infestation is named otodectic mange (Sweatman 1958) and, in general, the infested animals show discomfort, intense itch and even audition interference, depending on the level of parasitism (Gotthelf 2000).

Despite the importance of mites as causing agents of external otitis, information regarding their prevalence and the factors influencing their survival is lacking (Gram et al. 1994, Sotiraki et al 2001).

The objective of the present study was to evaluate the factors associated with the prevalence of $O$. cynotis infestations in dogs assisted at the Dermatology Sector of the Veterinary Hospital at Universidade Federal Rural do Rio de Janeiro, Brazil.

\section{MATERIALS AND METHODS}

\section{Size and selection of samples}

The number of animals to be sampled was calculated using the formulae $n=p(1-p)(1.96 / \Delta)^{2}$ (Sampaio 2002), with an estimated prevalence $(p)$ of $50 \%$, an error $(\Delta)$ of $6.5 \%$ and a confidence interval of $95 \%$. Considering the possibility of losses, an additional $10 \%$ of samples were added resulting in a total of 250 animals.

The study was carried out between October 2002 and May 2003 on the Dermatology Service of Universidade Federal Rural do Rio de Janeiro. The first 250 consecutive dogs assisted, independent of ear problems, were included in the sampling procedure after the agreement had been received from the owner.

\section{Anamnesis and physical examination}

All dog owners were interviewed, always by the same person and data from the present moment of the dogs were individually recorded.

The questionnaire included closed questions about the living environment, frequency of environment cleaning and contact with other animals and, the occurrence of itch in the ears and in other parts of the body. Environment cleaning includig picking up dog feces, vacuuming the carpet or sweeping off the floor for inside dogs, and hosing down the cement for outside dogs.

Opened questions were also asked about dogs' age. The ages were divided into categories as: puppies ( 0 and 18 month old), adults (19 to 84 months old) and elderly ( 85 months or older).

Data regarding the sex, breed, anatomic format of ear and, type and length of hair were recorded during the physical examination of dogs.

Before starting the study, a pilot test was carried out during the previous two weeks.

\section{Laboratorial diagnosis of Ototectes. cynotis}

Bilateral otoscopy was carried out in all dogs using a veterinary speculum. A dissection tweezers, protected with cotton, was introduced into each ear canal in order to search for O. cynotis mites. The obtained secretion was examined under a stereoscopic microscopy (Foley 1991). The mites found were placed on a glass slide, covered with a cover slip and the Hoyer solution was added. Identification of mites was carried out according to Flechtmann (1990).

\section{Analysis of data}

Data obtained from the interviews, physical examinations and laboratorial analysis were used to compose a data bank using the EPI INFO 2002 program (CDC 2003). The results from the parasitological examinations were used to calculate the prevalence of infestation (Martin et al. 1997). A descriptive analysis was carried out for the variable age of infested animals. The variables were tested regarding their association with presence of $O$. cynotis infestation, using the $\chi^{2}$ test and, when necessary, data were corrected through the Fisher exact test (Armitage \& Berry 1995) using the EPI INFO 2002 program (CDC 2002).

\section{RESULTS AND DISCUSSION}

The results of the parasitological examination on this study are described in Table 1 which is similar to Tonn (1963), Larsson (1987) and Rodriguez-Vivas (2003), but is different from the ones observed by Park et al. (1996) and Souza et al. (2003). The differences on the prevalences of Otodectes cynotis can be partially explained by the use of different diagnostic methods, by the sampling procedures used, and by the origin of the animals.

Regarding to pruritus in the ears and body, there was an association with the presence of mites $(p<0,001)$ (Table 2), what is also described by Kwochka (1987), Larsson (1987), Foley (1991) and Noli (2002), in their studies.

Table 1. Prevalence of dogs infested by Otodectes cynotis. Parasitological examination of both ears of the $\mathbf{2 5 0}$ dogs examined at the Dermatology Sector of Veterinary Hospital (Universidade Federal Rural do Rio de Janeiro), between October 2002 and May 2003

\begin{tabular}{cccc}
\hline \multicolumn{4}{c}{ Number and \% of ears infested } \\
\hline Right ear & Left ear & Both ears & Total of dogs \\
\hline $4(1.6 \%)$ & $2(0,8 \%)$ & $9(3.6 \%)$ & $15(6 \%)$
\end{tabular}

Table 2. Number of dogs examined for the diagnosis of ear mites and pruritus at the Dermatology Sector of the Veterinary Hospital (Universidade Federal Rural do Rio de Janeiro), between October 2002 and May 2003

\begin{tabular}{cccc}
\hline Otodectes & \multicolumn{3}{c}{ Pruritus } \\
cynotis & Positive & Negative & Total \\
\hline Positive & 12 & 3 & 15 \\
Negative & 61 & 174 & 235 \\
Total & 73 & 177 & 250
\end{tabular}

The infested animals ages ranged from 4 to 216 months and no associations were seen with the mite infestation (Table 3). Our results disagree with Kwochka (1987) and Larsson (1989), who suggest an age predisposition of dogs, with higher occurrence of infestation in animals under one year of age. And they also mention the acquisition of immunity by the adults. Although no significant association 
Table 3. Factors associated with Otodectes cynotis infestations in dogs (Dermatology sector of the Veterinary Hospital, Universidade Federal Rural do Rio de Janeiro), between October 2002 and May 2003

\begin{tabular}{|c|c|c|c|c|c|}
\hline \multicolumn{2}{|c|}{ Explicative variables } & \multirow{3}{*}{$\begin{array}{c}p \text { value } \\
0.20\end{array}$} & \multirow{3}{*}{$\begin{array}{c}\begin{array}{c}\text { Number of } \\
\text { examined } \\
\text { aminals }\end{array} \\
54\end{array}$} & \multirow{2}{*}{\multicolumn{2}{|c|}{$\begin{array}{c}\begin{array}{c}\text { Otodectes cynotis } \\
\text { infestation }\end{array} \\
\begin{array}{c}\text { Number } \\
\text { of positive } \\
\text { animals }\end{array}\end{array}$}} \\
\hline & & & & & \\
\hline \multirow[t]{3}{*}{ Age group } & Puppy & & & 6 & 11.1 \\
\hline & Adult & & 149 & 7 & 4.7 \\
\hline & Elderly & & 47 & 2 & 4.3 \\
\hline \multirow[t]{2}{*}{ Sex } & Male & $0.31^{*}$ & 110 & 8 & 7.3 \\
\hline & Female & & 140 & 7 & 5.0 \\
\hline \multirow[t]{2}{*}{ Breed } & Defined breed & $0.50^{*}$ & 174 & 10 & 5.8 \\
\hline & Mongrel & & 76 & 5 & 6.6 \\
\hline \multirow[t]{3}{*}{ Ear shape } & Erect & 0.66 & 46 & 4 & 8.7 \\
\hline & Semi-erect & & 30 & 2 & 6.7 \\
\hline & Pendent & & 174 & 9 & 5.2 \\
\hline Type & Straight & 0.18 & 99 & 8 & 8.1 \\
\hline \multirow[t]{2}{*}{ of hair } & Hard & & 111 & 7 & 6.3 \\
\hline & Curly & & 40 & 0 & 0 \\
\hline \multirow{3}{*}{$\begin{array}{l}\text { Length } \\
\text { of hair }\end{array}$} & Short & 0.14 & 63 & 7 & 11.1 \\
\hline & Medium & & 118 & 5 & 4.2 \\
\hline & Long & & 69 & 3 & 4.3 \\
\hline \multirow{5}{*}{$\begin{array}{l}\text { Living } \\
\text { environment } \\
\text { Frequency } \\
\text { of cleaning }\end{array}$} & Inside house & 0.03 & 134 & 4 & 3.1 \\
\hline & Outside house & & 116 & 11 & 9.5 \\
\hline & Once a week & 0.005 & 62 & 9 & 14.5 \\
\hline & 3 times a week & & 112 & 3 & 2.7 \\
\hline & Daily & & 76 & 3 & 3.9 \\
\hline \multirow{3}{*}{$\begin{array}{l}\text { Contact with } \\
\text { other animals }\end{array}$} & Dogs & 0.06 & 125 & 10 & 8.0 \\
\hline & Dogs and cats & & 12 & 2 & 16.7 \\
\hline & No contact & & 113 & 3 & 2.7 \\
\hline
\end{tabular}

* Fisher exact.

was observed, the modal age of infestation was 7 months what is in agreement with what has been observed in veterinary clinics, where higher frequencies of otodectic mange occur among puppies, possibly due to transmission from the bitch to puppies during breast feeding. As cited by Flechtmann (1990), Gotthelf (2000) and Marcondes (2001), this type of transmission is the most common way to acquire infestation. In spite of this, the mean age of positive animals was 3.7 years, and the median age was 3 years; what means that $50 \%$ of the infested dogs were 3 years old or younger and $50 \%$ were 3 years old or older.

With regard to the sex of infested animals no significant differences were seen between prevalence rates in males and in females (Table 3). Some authors as Park et al. (1996) and Rodriguez-Vivas et al. (2003), this last one using logistic regression, also demonstrated that there is no preference of sex in mite infestations. However, these results are not in agreement with Larsson (1987) who states that otopathies, including the parasitic ones, have higher occurrence in males, but the author did not test the significance of the observed differences.

No associations were seen between the breed of the dogs and mite infestations (Table 3 ). The same results were observed by Park et al. (1996) although no statistical analysis had been carried out. However, if submitted to the $\chi^{2}$ test, the data presented by these authors indicate significant differences on prevalence rates according to the breed, being higher in mongrel dogs. On the other hand, these differences probably are not due to the breed itself but due to some variables associated to it, such as the environmental and care conditions these dogs have. In general, mongrel dogs are raised under poorer conditions.

No associations were seen between the anatomic shape of ears and prevalence of O. cynotis (Table 3 ). Similar results have been reported by Tacal Jr \& Sison (1969), who analyzed the data through the $U$ test and did not observe significant differences. Grono (1969) used the Chi-square test to evaluate data and found a $p<0,001$, demonstrating that there is an association between the presence of mite and the type of ear. Semi-erect and pendent were the most affected type of ears. Guimarães et al. (2001) affirm that infestation is significantly associated with semi-erect ears. However, the authors did not propose any hypothesis to explain this association.

No associations were seen between $O$. cynotis infestation and the type and length of hair (Table 3). Larsson (1989) states that there is no predisposition regarding the type of hair and mite infestation, although the author did not carry out statistical analysis. But in 1987, this same author evaluated the percentage of otopathies in dogs with different lengths of hair. And also reported higher predisposition to any kind of otopathy, including otodectic mange, in animals with long hair, but the analysis was based only on the highest percentual of affected animals.

There was an association between the living environment and $O$. cynotis infestation, with higher prevalence in animals living outside the house. The frequency of environment cleaning was significantly associated to the infestation. Dogs living in environments in which cleaning was carried out only once a week had higher prevalence of infestation, indicating that environment cleaning is an important factor in preventing the infestation (Table 3 ). The mite 0 . cynotis feed on organic matter and may stay viable for long periods of time in favorable environmental conditions that had been occupied by infested animals (Larkin \& Gaillard 1981, Sosna \& Medleau 1992, Coleman \& Atwell 1999, Angus 2004). Cement and grass promote protection to mites, favoring their survival. Lower frequencies in environment cleaning also favor infestation as poor hygienic conditions lead to high accumulation of food for the mites. In addition, Souza et al. (2003) suggest that mite infestations are more common in street dogs, living under poor environmental conditions.

Among the $80 \%$ of infested dogs having contact with other animals, $75 \%$ had contact with animals living within the same house and $25 \%$ had contact with street animals. Many authors have cited the direct contact with other animals as the most frequent method of $O$. cynotis transmission. However, associations were not seen between infestation of $O$. cynotis and contact with other animals, neither for the same species nor for other species (Table 3). But the lack of association may be related to the low number of subjects in one of the categories outcomes in this variable, equalizing groups that show very different percentages (Sampaio, 
2002). On the other hand, Tonn (1961) carried out a study on artificial infestation of mites on animals from the same species and on animals from different species, and concluded that $O$. cynotis is easily transmitted from infested animals to other susceptible animals from the same species; however transmission is more difficult from a cat to a dog and vice-versa.

It has to be emphasized that for the determination of the relative contribution of each variable on $O$. cynotis infestation, it would be recommended to develop a multivariable analysis. However, on this study, there were not enough outcomes for its execution. Katz (2006) suggests at least ten outcomes for each independent variable.

In conclusion, no evidences were provided to support that age, sex, breed, size, shape of ears, type and length of hair and contact with other dogs are potential factors of risk for $O$. cynotis infestations. However, the living environment where the animals live, and the frequency of environmental cleaning facilitate the infestation. The occurrence of pruritus was associated with the presence of mites, suggesting being an effect of the infestation. This way, it is recommended the execution of other studies to elucidate the role of each variable.

\section{REFERENCES}

Angus J.C. 2004. Otic cytology in health and disease. Vet. Clin. Small Anim. Pract. 34:411-424.

Armitage P. \& Berry G. 1995. Statistical inference, p.132-141. In: Armitage P. \& Berry G. (ed.), Statistical Methods in Medical Research. 3rd ed. Blackwell Science, Cambridge.

August J.R. 1988. Otitis externa, a disease of multifactorial etiology. Vet. Clin. Nort. Am. Small Anim. Pract. 18:731-742.

CDC, EPI INFO 2002. Disponível em: http://www.cdc.gov/epiinfo/ index.htm. Acesso em: 7 de abril de 2003.

Chickering W.R. 1988. Cytologic evaluation of the otic exudates. Vet. Clin. Nort. Am. Small Anim. Pract. 18:773-782.

Coleman G.T. \& Atwell R.B. 1999. Use of fipronil to treat ear mites in cats. Aust. Vet. Pract. 29:166-168.

Flechtmann C.H.W. 1990. Ácaros Astigmata ou Sarcoptiformes, p.157159. In: Flechtmann C.H.W. (ed.), Ácaros de Importância Médico Veterinária. $3^{\mathrm{a}}$ ed. Nobel, São Paulo.

Foley R.H. 1991. Parasitic mites of dogs and cats. Compend. 13:783801.

Gotthelf L.N. 2000. Primary causes of ear disease, p.88-90. In: Gotthelf L.N (ed.), Small Animal Ear Diseases. 1st ed. W.B. Saunders, Philadelphia.

Gram D., Payton A.J., Gerig T.M. \& Bevier D.E. 1994. Treating ear mites in cats: a comparison of subcutaneous and topical ivermectin. Vet. Med. 89:1122-1125.

Grono L.R. 1969. Studies of the ear mite, Otodectes cynotis. Vet. Rec. 85:6-8.

Guimarães J.H., Tucci E.C. \& Barros-Battesti D.M. 2001. Ácaros, p.2728. In: Guimarães J.H., Tucci E.C. \& Barros-Battesti D.M. (ed.), Ectoparasitos de Importância Veterinária. $1^{a}$ ed. Plêiade, São Paulo.

Katz M.H. 2006. Setting up a multivariable analysis. p. 73-81. In: Katz M.H. (ed.), Multivariable analysis. 2nd ed. Cambridge, New York.
Kwochka K.W. 1987. Mites and related disease. Vet. Clin. Nort. Am. Small Anim. Pract. 17:1263-1284.

Larkin A.D. \& Gaillard G.E. 1981. Mites in the cat ears: a source of cross antigenicity with house dust mites, preliminary report. Ann. Allerg. 46:301-304.

Larsson C.E. 1987. Contribuição ao estudo das otopatias de cães e gatos. Tese de Livre Docência, Faculdade de Medicina Veterinária e Zootecnia, USP, São Paulo, SP. 180p.

Larsson C.E. 1989. Dermatologia veterinária-dermatites parasitárias dos carnívoros domésticos: sarnas sarcóptica, notoédrica e otoacaríase. Comun. Cient. Fac. Med. Vet. Zootec. Univ. São Paulo 13:7-17.

Marcondes C.B. 2001. Ácaros (carrapatos e outros), p.305-306. In: Marcondes C.B. (ed.), Entomologia Médica e Veterinária. $1^{\underline{a}}$ ed. Atheneu, São Paulo.

Martin S.W., Meek A.H. \& Willeberg P. 1997. Medida de la frecuencia de la enfermidade y de la produccion, p.62. In: Martin S.W., Meek A.H. \& Willeberg P. (ed.), Epidemiología Veterinaria: principios y métodos. $1^{\mathrm{a}}$ ed. Acribia S.A., Zaragoza.

McCallum Jr P.P. 1967. Inapparent infestation of Otodectes cynotis in dog and cat. Georg. Vet. 19:8-9.

Noli C. 2002. Principais ectoparasitoses de cães e gatos. Hora Vet., Porto Alegre, 125:45-50.

Park G.S., Park J.S., Cho B.K., Lee W.K. \& Cho J.H. 1996. Mite infestation rate of pet dogs with ear dermatoses. Kor. J. Parasitol. 34:143-150.

Pullar E.M. 1946. A survey of Victorian canine and vulpine parasites. Aust. Vet. J. 22:112-118.

Rodriguez-Vivas R.I., Ortega-Pacheco A., Rosado-Aguilar J.A. \& Bolio G.M.E. 2003. Factors affecting the prevalence of mange-mite infestations in stray dogs of Yucatán, Mexico. Vet. Parasitol. 115:61-65.

Rose W.R. 1976. Otitis externa. 5. Otoacariasis. Vet. Med. Small Anim. Clinic. 5:1280-1283.

Sampaio I.B.M. 2002. Estudo de dispersão de freqüência, p.107-121. In: Sampaio I.B.M (ed.), Estatística Aplicada à Experimentação Animal. $2^{\underline{a}}$ ed. Fundação de Ensino e Pesquisa em Medicina Veterinária e Zootecnia, Belo Horizonte.

Scott D.W., Miller W.H. \& Griffin C.E. 2001. Parasitic skin diseases, p.450452. In: Scott D.W., Miller W.H. \& Griffin C.E. (ed.), Muller \& Kirk's Small Animal Dermatology. 6th ed. W.B. Saunders, Philadelphia.

Sosna C.B. \& Medleau L. 1992. External parasites: life cycles, transmission and the pathogenesis of disease. Vet. Med. 6:538-547.

Sotiraki S.T., Koutinas A.F., Leontides L.S., Adamama-Moraitou K.K. \& Himonas C.A. 2001. Factors affecting the frequency of ear canal and face infestation by Otodectes cynotis in the cat. Vet. Parasitol. 96:309315.

Souza C.P., Fernandes J.I., Torres F.O., Verocai G.G., Soares L.B., Valim F.M., Soares L.C., Peres V.R., Souza M.M.S. \& Scott F.B. 2003. Freqüência de ácaros Otodectes cynotis em cães de rua e determinação da microbiota dos seus condutos auditivos. In: Proc. $3^{\text {a }}$ Conf. Sul-Americana Med. Vet., Rio de Janeiro, p.54.

Sweatman G.K. 1958. Biology of Otodectes cynotis, the ear canker mite of carnivores. Can. J. Zool. 36:849-862.

Tacal Jr J.V. \& Sison J.A. 1969. Otodectes cynotis: a study of inapparent infestations in dogs and cats. Philip. J. Med. Vet. 8:81-91.

Tonn R.J. 1961. Studies on the ear mite Otodectes cynotis, including life cycle. Ann. Entomol. Soc. Am. 54:416-521.

Tonn R.J. 1963. The ear mite, Otodectes cynotis in dogs: a report of two surveys. J. Econ. Entom. 56:892.

Woody B.J. \& Fox S.M. 1986. Otitis externa: seeing past the signs to discover the underlying cause. Vet. Med. 81:616-624. 